\title{
A new coprophilous species of Perichaena (Myxomycetes) from the Russian Arctic (the Taimyr Peninsula and the Chukchi Peninsula)
}

\author{
YURI K. NOVOZHILOV and MARTIN SCHNITTLER
}

\begin{abstract}
NOVOZHILOV, Y. K. \& SCHNITTLER, M. 2000: A new coprophilous species of Perichaena (Myxomycetes) from the Russian Arctic (the Taimyr Peninsula and the Chukchi Peninsula). - Karstenia 40: 117-122. Helsinki. ISSN 0453-3402.

Perichaena taimyriensis Novozh. \& Schnittler is a new, undescribed coprophilous myxomycete species characterised by the absence of a capillitium and its pilate spore ornamentation. Collections from the Taimyr Peninsula and the Chukchi Peninsula, Russia, were recorded from dung of reindeer (Rangifer tarandus L.) in forest-tundra and tundra communities. A description of $P$. taimyriensis and scanning electron photographs are presented. Characters distinguishing this species from Perichaena corticalis (Batsch) Rostaf. var. liceoides (Rostaf.) G. Lister are given. The taxonomic limits of this species are discussed. Apparently, P. taimyriensis represents an intermediate taxon between Perichaena and Licea but can be tentatively placed within the genus Perichaena.
\end{abstract}

Key words: Perichaena taimyriensis, coprophilous myxomycetes, ultrastructure, Russia, Arctic

Yuri K. Novozhilov, V.L. Komarov Botanical Institute of the Russian Academy of Sciences, Prof. Popov Street, 2, 197376 St. Petersburg, Russia

Martin Schnittler, Fairmont State College, Fairmont, West Virginia 26554-2470, U.S.A.

\section{Introduction}

The genus Perichaena was erected by Fries (1817) for Perichaena populina Fr. (= P. corticalis (Batsch) Rostaf.) and based on combination of several characters: yellow colour of the spores in mass, usually a double-layered peridium, and the absence of spiral bands on the capillitial threads. The majority of Perichaena species have a well-developed capillitium, but some species appear to lack a capillitium, approaching the genus Licea. P. corticalis var. liceoides (Rostaf.) $\mathrm{G}$. Lister is a good example of a species with a reduced capillitium that appears not to fit the traditional concepts of Perichaena and is a facultative coprophilous species regularly found on dung of herbivorous animals (Gilert 1990, Eliasson \& Keller 1999, Lister 1911, 1925).
During a study of myxomycetes of the Russian Arctic, we observed a perichaenaceous taxon apparently without a capillitium while examining moist chamber cultures of dung of reindeer (Rangifer tarandus L.) collected from one site in the Taimyr Peninsula and from one site in the Chukchi Peninsula. The sporangia of this myxomycete consisted of small, scattered, orange-yellow to apricot-orange, globose to subglobose fruitings. Due to the structure of the peridium, colour of the spore mass and apparent lack of a capillitium, it was suspected that these sporangia represented a species of Perichaena or Licea. The eight specimens consisting of several hundred sporangia are in very good condition. Observation of material revealed that this is an un- 
described species of Perichaena, which is described below.

\begin{abstract}
Methods
Samples of fecal material were placed on filter paper in Petri dishes. Cultures were wetted with distilled water, adjusted to $\mathrm{pH} 7.0$ and maintained up to 2 months under diffuse daylight at room temperature $\left(22-23{ }^{\circ} \mathrm{C}\right)$. After four weeks or more several hundred sporangia developed of a distinct and undescribed species of myxomycete. Some sporangia were used in attempts to establish spore to spore cultures but these were unfortunately unsuccessful. Sporangia were preserved as permanent slides in polyvinyl lactophenol. Air-dried sporangia were studied with a JEOL $35 \mathrm{c}$ scanning electron microscope at St. Petersburg; mounted on copper stubs using double-sided sticky film and sputter-coated with gold up to 200-500 $\AA$ thickness. Terms for taxonomic descriptions are taken from Lado and Pando (1997) and Rammeloo (1974). Abbreviations of authors' names follows Kirk and Ansell (1992). Colour descriptions of sporangia are given according to Petersen (1996).
\end{abstract}

Perichaena taimyriensis Novozh. \& Schnittler, sp. nova - Fig 1. A-H

Sporangia sessilia sparsa vel gregaria, globosa, subglobosa, rarius pulvinata vel subelongata, 0.2-0.7 mm diam., lutea (23; Petersen 1996) vel aurantica-lutea (24; Petersen 1996), nitida, sed sine adumbratie metallica vel iridescenti. Peridium bistratosa; stratum extimum et stratum internum inter se arcte connexae sunt. Stratum extimum asperum, excrescentiis tuberculatis numerosis, fragile, sine calce, ope microscopii optici luteo-brunneum, impellucium contra lucem pellucentem de causa depositionis granularis. Stratum internum membranaceum, sat elasticum, tenue, diaphanum, flavidum ope microscopii optice contra lucem pellucentem difficulter discernendum, sine calce, depositionibus granularibus et ornamentatione conspicua. Hypothallus difficulter discernendus. Capillitium nullum. Sporae luteae in massa, flavae ope microscopii optici in lucem percurrens, liberae, globosae, pachydermaticae, minute verrucosae ope microscopii optici, (13-)13.5-14.5(-15) um diam. Sporae parie latitudine 1-1.5 $\mu \mathrm{m}$, aequaliter incrassate, sine poro germinationis. Sporae verrucosis e stylis brevibus et capitulis 0.2-0.5 $\mu \mathrm{m}$ latis, liberibus vel confluentibus, 3-6 strumulosis, irregularibus compositis ornatae. Plasmodio ignoto.
Type: Russia. The Taimyr Peninsula, the watershed of the Kheta River, $71^{\circ} 31^{\prime} \mathrm{N}, 99^{\circ} 24^{\prime} \mathrm{E}$, at elevations $50 \mathrm{~m}$ below sea level, forest-tundra, from moist chamber on dung of reindeer (Rangifer tarandus L.), 23.VII.1996 Novozhilov 204007 (LE, holotype; BPI, FWVA, isotypes).

Additional specimens examined: Russia. The Chukchi Peninsula, southern part of Pekul'ney Range, Pekul'ney Range, upper Severny Pekul'neyveem River, 65³3' N, $174^{\circ} 16^{\prime} \mathrm{E}$, shrub tundra, from moist chamber on dung of reindeer ( $R$. tarandus L.), 09.VIII.1996 Novozhilov 49329 (LE).

Sporangia crowded, gregarious or scattered, globose to subglobose, pulvinate to elongated, 0.2 $0.7 \mathrm{~mm}$ in diameter. Sessile on a constricted base, not iridescent but glossy and shining, buff yellow, orange yellow (23; Petersen 1996) to apricot orange (24; Petersen 1996), dehiscing more or less irregularly. Peridium persistent, double; outer layer closely adherent to the membranous inner layer, rough, bearing numerous tubercles, more or less cartilaginous, brittle, fairly evenly thick, noncalcareous, yellow-brown in transmitted light, shining, opaque with granular deposits. Inner layer membranous, rather elastic, thin, delicate, translucent in transmitted light, noncalcareous. Hypothallus inconspicuous, scanty. Capillitium apparently absent.

Spores orange-yellow in mass, bright to buff yellow in transmitted light, globose, wall uniformly thickened, neither areolate nor with a germination pore, minutely roughened (asperulate) under an oil immersion lens, or verruculose (delicately warted), complete and evenly ornamented, (13-)13.5-14.5(-15) $\mu \mathrm{m}$ in diameter, the spore wall about $1-1.5 \mu \mathrm{m}$ thick.

The epispore belongs to the pilate type (Rammeloo 1974). Verrucae consist of small pila which are more or less evenly distributed on the spore surface; the capita of pila are separate or sometimes connected to each other and relatively large, $0.2-0.5 \mu \mathrm{m}$ wide, with 3-6 small tubercles.

Etymology: From the name of the location the Taimyr Peninsula (north-central Siberia).

Distribution: Known only from the Taimyr Peninsula, and the Chukchi Peninsula, Russia.

Ecology and habitat. Specimens obtained from moist chamber cultures on dung of reindeer. Apparently the sporangia develop only on the dung of herbivorous animals. 


\section{Discussion}

The morphology of the sporangia of Perichaena taimyriensis is shown in Fig 1. A, B. In habit and in its habitat, $P$. taimyriensis resembles Perichaena corticalis (Batsch) Rostaf. var. lice- oides (Rostaf.) G. Lister. The most obvious difference between the two species is in the size of its spores and in some microscopic characteristics. Perichaena taimyriensis has spores 13.5-14.5 $\mu \mathrm{m}$ in diameter (Fig 1. F, G). The spore ornamentation (Fig.1. H), and thickness of the spore wall
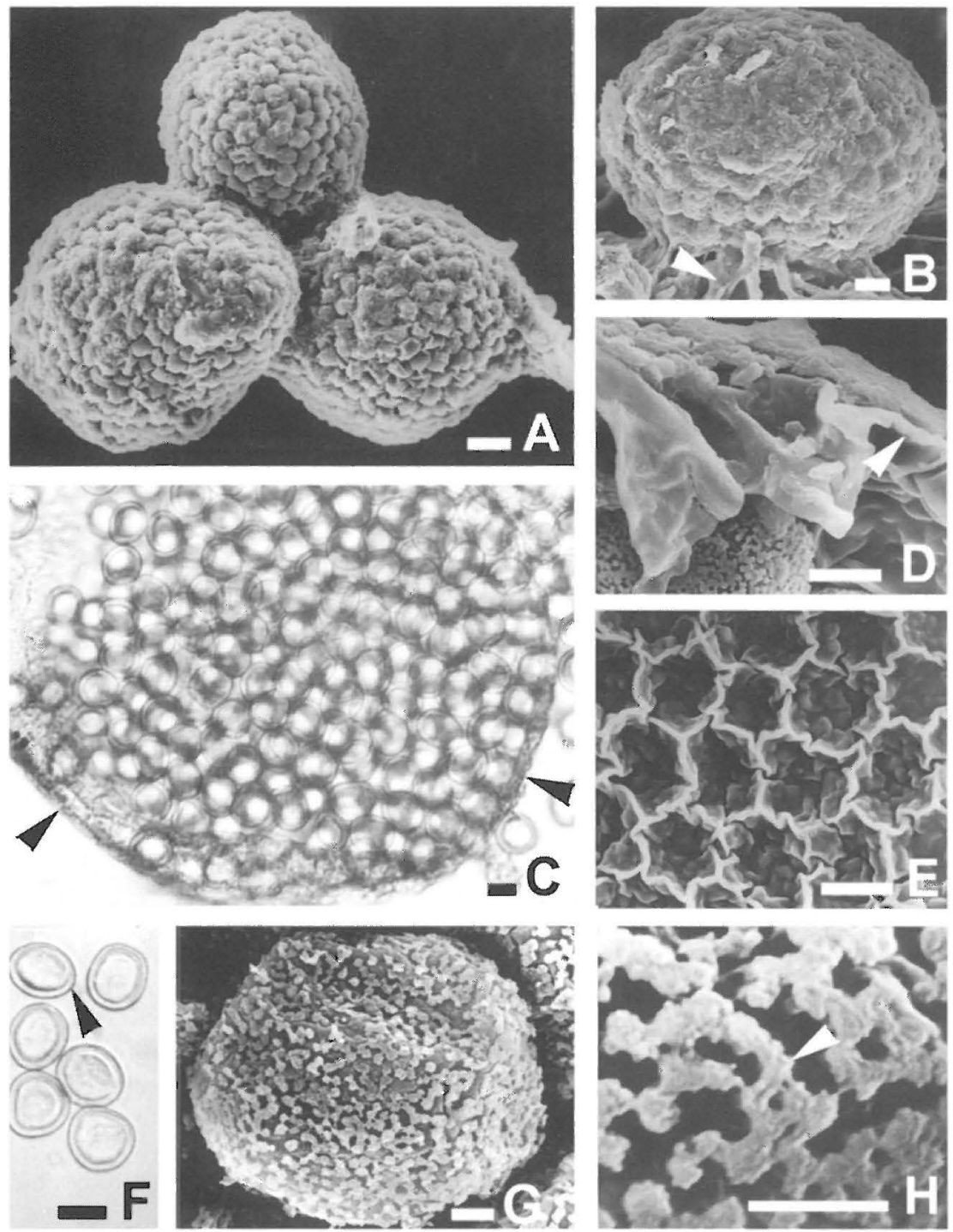

Fig. 1. Perichaena taimyriensis (LE 204007), scanning electron microphotographs (A, B, D, E, G - H), light microphotographs $(\mathrm{C}, \mathrm{F})$. A) Top view of closed sporangia. Bar $=10 \mathrm{~mm}$. B) Side view of closed sporangium, note the hypothallus (arrow). Bar $=10 \mathrm{~mm}$. C) Polyvinyl lactophenol mount of whole sporangium, note the peridium (arrows). Bar $=10 \mathrm{~mm}$. D ) Double-layered peridium. The outer layer of the peridium is closely adherent to the membranous inner layer (arrow). Bar $=10 \mathrm{~mm}$. E) The honeycomb-like surface of the inner layer of the peridium. Bar $=10 \mathrm{~mm}$. F) Polyvinyl lactophenol mount of spores in optical section, note the thickened spore wall (arrow). Bar $=10 \mathrm{~mm}$. G) Spore. Bar $=1 \mathrm{~mm}$. H) Detail of spore ornamentation, note the capita of adjacent pila form an incomplete reticulum. $\mathrm{Bar}=1 \mathrm{~mm}$. 
(Fig. 1. F) of P. taimyriensis make this species unmistakable. The most distinguishing feature of the spores of $P$. taimyriensis is the distinct pilate type of spore ornamentation. In P. taimyriensis pila (capitate warts) are wide, relatively short and can be detected only under oil immersion, but are clearly seen with the scanning electron microscope (Fig. 1. H). The pila are fully differentiated into a baculate and a capitate portion. The capita bear 3-6 small tubercles. The capita of adjacent warts tend to coalesce and form an incomplete reticulum (Fig. 1. H). According to the original description of $P$. corticalis var. liceoides (Rostafínski 1875) this species has spores 9.2-10 $\mu \mathrm{m}$ in diameter. The spores of Rostafinski's type collections and a specimen (BM 3140) cited by Lister (1911) are evenly covered with prominent spines and can be related to the baculate type (Figs. 8, 15; Gilert 1990). Numerous intermediate forms, from the baculate type (spinulose) to pilate type (verrucose) of ornamentation were also found in P. corticalis (Batsch) Rostaf. and P. depressa Lib. (Rammeloo 1974) where, however, the warts are much higher and the capita of the warts are much smaller than in $P$. taimyriensis.

The double-layered peridium (the outer layer granular, the inner layer membranous) is the most common type of peridium in Perichaena (Keller \& Eliasson 1992; Martin \& Alexopoulos 1969). The peridium of $P$. taimyriensis is clearly double (Fig1. C, D, E). The structure of the inner surface of the inner layer of the peridium is smooth and closely matches observations made in specimens of $P$. corticalis var. liceoides (Figs. 4, 10, 11, 28; Gilert 1990). The structure of the outer surface of the peridium is not exactly the same in the two taxa. The outer surface of the peridium in $P$. taimyriensis is rough and encrusted with granular deposits (Fig 1. D), similar to the outer surface of the peridium of $P$. corticalis var. liceoides (Fig. 3; Gilert 1990). However, the surface of the peridium in $P$. taimyriensis is clearly demarcated by tubercles (Fig. 1. A, B), while in P. corticalis var. liceoides it is more smooth (Figs. 1, 2; Gilert 1990).

The apparent absence of a capillitium in $P$. taimyriensis aligns this taxon closer to Licea (Liceales), in particular with the yellow-orange spored species, such as Licea tenera E. Jahn. However, L. tenera according to the original description (Jahn 1918), has faintly spinulose spores, 10-12 (13) $\mu \mathrm{m}$ in diameter. The spore wall in $L$. tenera has thinner and paler area on one side (Keller \& Brooks 1977), while the spores of $P$. taimyriensis are verruculose and the spore wall is uniform in thickness. The presence or absence of a capillitium as a taxonomically important character has been questioned (Alexopoulos 1976; Eliasson \& Lundqvist 1979; Keller \& Brooks 1971). Eliasson (1977) has pointed out that Perichaena appears to have some clear affinities with some species of Licea, although the two genera are traditionally separated in monographic treatments. Some species, such as Perichaena brevifila H.W. Keller \& T.E. Brooks, P. corticalis (Batsh) Rostaf., P. quadrata T. Macbr. and P. syncarpon T.E. Brooks, have a reduced capillitium or the capillitium may be absent as in P. corticalis var. liceoides (Keller \& Brooks 1971; Keller \& Eliasson 1992). On the other hand, Gilert (1996) has shown that some species Licea may have a reduced capillitium (e.g. Licea minima Fr., L. pusilla Schrad., and L. kleistobolus G.W. Martin).

The taxonomic line of separation between Perichaena and Licea is unclear. Consequently, placing P. taimyriensis in Perichaena is largely a matter of opinion. Apparently, P. taimyriensis represents a taxon intermediate between Perichaena and Licea. It can be tentatively placed within the genus Perichaena that includes species with a reduced capillitium and facultatively coprophilous species.

Currently, about 99 species representing 23 genera have been identified primarily from dung of herbivorous animals (Cox 1981; Eliasson \& Keller 1999; Eliasson \& Lundqvist 1979; GarciaZorron 1977; Ing 1994). Most species of myxomycetes found on dung are more usually associated with soil and plant litter. Apart from $P$. taimyriensis, Kelleromyxa fimicola, and Trichia brunnea, the vast majority of species on dung was also recorded from other substrata and utilise only occasionally dung. These species noted above, including $P$. taimyriensis, have a strikingly thickened the spore walls (Fig. 1.F), which may be an adaptation to passage through the intestinal tracts of herbivorous animals (Eliasson $\&$ Keller 1999). Due to the absence of experimental data, it is impossible to state whether $P$. taimyriensis is endocoprophilous or this species can be regarded as facultatively a coprophilous organism inhabiting ground litter that comes occasionally in contact with dung of herbivores. Perhaps herbivores can be vectors in Arctic ter- 
restrial ecosystems for some myxomycetes, including P. taimyriensis. For example, Stephenson and Landolt (1992) isolated plasmodia of myxomycetes in fecal samples from the white-footed deer mouse (Peromyscus leucopus Rafinesque) and the big brown bat (Eptesicus fuscus Beauvois). Unfortunately, their efforts to induce fruiting in order to enable identification were unsuccessful, but evidence suggests that spores or microcysts survive passage through the digestive tract. In the Taimyr Peninsula, myxomycetes are well known from the dung of herbivorous animals, such as the lemming (Lemmus lemmus), hare (Lepus sp.), reindeer (Rangifer tarandus), and polar partridge (Lagopus lagopus). However, this microhabitat was not very productive in the Taimyr Peninsula (Novozhilov et al., 1999). With only six species recorded from 25 substratum samples, the dung of herbivorous animals was significantly less productive than in arid zones of the world (Blackwell \& Gilbertson 1980; Novozhilov \& Golubeva 1986). The main reason may be the relative acidity of dung of herbivorous animals in the Taimyr Peninsula $(\mathrm{pH} 4.6-7.3$, mean $5.9 \pm 0.1$ ). Presumably, all other conditions should be sufficient for myxomycete growth and development. Reindeer are the most abundant large herbivorous mammals in the Taimyr Peninsula and the Chukchi Peninsula. They feed on vegetation such as grasses, leaves, mosses, and lichens and move regularly each year from tundra to coniferous forests. The total population of the Taimyr Peninsula wild reindeer consists of about 600000 animals and during their annual life cycle, the population covers a territory of about 10700000 sq. km (Chernov \& Matveyeva 1997).

It appears that reindeer can be a vector of some coprophilous species such as $P$. taimyriensis in the Eurasian tundra. However, to reveal these relationships between reindeer and coprophilous myxomycetes more research is necessary.

Acknowledgments: We acknowledge logistical support provided by Dr. D. Bolsheianov of the Arctic and Antarctic Research Institute, St. Petersburg, Russia. Appreciation is extended to Dr. I. Yu. Kirtsideli for collecting substratum samples for moist chambers in some areas of the Taimyr Peninsula. We also wish to express our thanks to L.A. Karzeva, St. Petersburg, for technical assistance during the SEM-investigations and to Dr. A. Borodina for writing the Latin diagnosis. Prof. Harold W. Keller (Central Missouri State University) and Prof.
Uno H. Eliasson (Göteborg University, Sweden) made valuable comments relating to the collection of Perichaena taimyriensis. This work was supported in part by grants (N 96-04-48209, N 98-04-48120, 9807-90346) from the Russian Foundation for Basic Research [RFBR].

\section{References}

Alexopoulos, C.J. 1976: Absence of a capillitium as a taxonomic character in the myxomycetes. - Trans. Br. Mycol. Soc. 66: 329.

Blackwell, M. \& Gilbertson, R.L. 1980: Sonoran Desert myxomycetes. - Mycotaxon 11: 139-149.

Chernov, Y.I. \& Matveyeva, N.V. 1997: Arctic ecosystems in Russia. - In: Wielgolaski, F.E. (ed.), Ecosystems of the World 3. Polar and Alpine tundra: 361507. Elsevier, Amsterdam \& Tokyo.

Cox, J.L. 1981: Notes on coprophilous Myxomycetes from the Western United States. - Mycologia 73: 741-747.

Eliasson, U.H. 1977: Recent advances in the taxonomy of myxomycetes. - Bot. Notiser 130: 483-492.

Eliasson, U. \& Keller, H.W. 1999: Coprophilous myxomycetes: updated summary, key to species, and taxonomic observations on Trichia brunnea, Arcyria elaterensis, and Arcyria stipata. - Karstenia 39: 1-10.

Eliasson, U.H. \& Lundqvist, N. 1979: Fimicolous myxomycetes. - Bot. Notiser 132: 551-568.

Fries, E.M. 1817: Symbolae Gasteromycorum ad illustrandam Floram Suecicam. II.

Garcia-Zorron, N. 1977: Mixomicetos coprofilos del Uruguay. - Revista biologica del Uruguay 54: 47-50.

Gilert, E. 1990: On the identity of Perichaena liceoides (Myxomycetes). - Mycol. Res. 94: 698-704.

Gilert, E. 1996: Morphological and ultrastuctural features in selected species of Licea (Myxomycetes). Nord. J. Bot. 16: 515-546.

Ing, B. 1994: The phytosociology of myxomycetes. The New Phytologist 126: 175-202.

Jahn, E. 1918: Myxomycetenstudien. 9. Bemerkungen über einige seltene oder neue Arten. - Ber. Dtsch. Bot. Ges. 36: 660-669.

Keller, H.W. \& Brooks, T.E. 1971: A new species of Perichaena on decayed leaves. - Mycologia 63: 657663.

Keller, H.W. \& Brooks, T.E. 1977: Corticolous myxomycetes VII: contribution toward a monograph of Licea, five new species. - Mycologia 69: 667-684.

Keller, H.W. \& Eliasson, U.H. 1992: Taxonomic evaluation of Perichaena depressa and P. quadrata based on controlled cultivation, with additional observations on the genus. - Mycol. Res. 96: 1085-1097.

Kirk, P.M. \& Ansell, A.E. 1992: Authors of Fungal Names. - C.A.B. International, Wallingford. 95 pp.,

Lado, C. \& Pando, F. 1997: Flora Mycologica Iberica, Vol. 2. Myxomycetes, I. Ceratiomyxales, Echinosteliales, Liceales, Trichales. 1. ed. - Stuttgart: J. Cramer, Madrid, Berlin. 323 pp.

Lister, A. 1911: A monograph of the Mycetozoa. $2^{\text {rd }}$ ed., revised by G. Lister - British Museum, London. 302 pp. 200 pls. 
Lister, A. 1925: A monograph of the Mycetozoa. $3^{\text {rd }}$ ed., revised by G. Lister. - British Museum, London. 296 pp. 222 pls.

Martin, G.W. \& Alexopoulos, C.J. 1969: The Myxomycetes. - Univ. Iowa Press, Iowa City. 561 pp.

Novozhilov, Y.K. \& Golubeva, O.G. 1986: Epiphytic myxomycetes from the Mongolian Altai and the Gobi desert [In Russian]. - Mikologija i fitopatologija 20: 368-374.

Novozhilov, Y.K., Schnittler, M. \& Stephenson, S.L. 1999: Myxomycetes of the Taimyr Peninsula (northcentral Siberia). - Karstenia 39: 77-97.
Petersen, J.H. 1996: The Danish Mycological Society's Colour-chart. - Foreningen til Svampekundskabens Fremme, Greve.

Rammeloo, J. 1974: Structure of the epispore in the Trichiaceae (Trichiales, Myxomycetes). As seen with the scanning electron microscope. - Bull. Soc. Roy. Bot. Belg. 107: 353-359.

Rostafínski, J. 1875: Sluzowce (Mycetozoa) Monografia. - Paris. 275 pp.

Stephenson, S.L. \& Landolt, L.C. 1992: Vertebrates as vectors of cellular slime moulds in temperate forests. - Mycol. Res. 96: 670-672. 